\title{
JOYCES STEMME
}

\section{Phillip Sollers}

Joyce? Det er tilstrækkeligt at høre hans stemme. For at være hel præcis: hans indspilning af et fragment fra Finnegans Wake. Den sproglige opfindsomheds frihedserklæring. Hans frihed. Hans ureducérbare behændighed. Lyt til det, De vil lære mere af det på ti minutter end af 10 års læsning: lyt til det, jeg beder Dem, og hvis ikke, undlad da at citere Joyce, lad ikke som om De interesserer Dem for ham 1 .

Hvad er det, man dér hører for første gang? Smidigheden; dristigheden; rollernes mangfoldighed, fra det dybe til det skingre, fra det hviskende til det næsten skregne; parodien; den fornyede lamslåelse over at den er så vidunderlig og dum, menneskehedens historie; den sarte sindsbevægelse; efterligningen af sukket, og af sukkets suk; mørkets frembrud og vandene og tidens strømmen; det udholdende liv og den dødelige træthed; flodernes brusen og stenenes rullen pa deres bund; vinden i bladene; den barnagtige lysts stønnen; den gale og undertrykte liderlighed; den kvindelige manierisme.

Flip! Flep! Flap! Flop! Mens man lytter, må man give sig hen til siderne 213-216 i Finnegans Wake. Ulæselig, den bog? Uoversættelig? Lyt efter, lyt efter. Snart stiger fra nattens dyb denne forunderligt vise stemme, en smule euforisk, forslagen, hærdet af hundrede sorger, men altid melodisk; denne den blindes faste stemme, der trækker søvnens grene og slør til side, og det er som kom den 
gamle Homer, dér, evigung, til Dem gennem et væv af tusinde eventyr, af tusinde fortællinger, af tusind og et sprog, han har fundet på sin pilgrimsfærd under vandene, stavelser der svarer og oplyser hinanden, oplivede af det nye åndepust. "Lord save us! Ho, talk save us!" Frels os, Ord-Gud! For alt og alle, her er glimtet, gnisten som ikke forsvinder i mørket. Ordene simpelthed, grebne på særlig vis, på særlig vis omfattede af lyden. "Night!" Genopstandelsen afventes ironisk løssluppent. Det er den vågne venten ved daggry, fuld af smerte, af vanvittige grin og af medfølelse.

Det er opera, det er et oratorie, det er en messe. For tidernes ende, naturligvis, men tidernes ende har intet obskurt over sig, og endnu mindre obskurantistisk; apokalypsen hæver ikke stemmen, intet er uden udvej, ingen fortvivlelse. Joyce, katolik? Ja da, men på den anden side enhver enfoldig fromhed, i et rum af brændende og blasfemiske ekkoer. Det er det øjeblik, hvor alt rejser sig og mødes i en universel og unik skælven. Øjeblik, hvor man fortæller det utrolige epos om forhåbningerne og skuffelserne. De kan ikke læse Joyce? Så åbn i det mindste en af de bedste romaner, der nogensinde er skrevet, hans biografi ved Richard Ellmann². Der vil De kunne se én af den moderne tids, sammen med Freud, sjældne helte i virksomhed. Videnskaben om drømmene? Jamen, her har De den: "Ved De, at vi læser, når vi drømmer? Jeg tror faktisk, at vi taler under vor søvn. Men vi formår ikke at tale lige så hurtigt som vi læser, og vore drømme opfinder en grund, der kan berettige vor langsommelighed."

Her har De Joyce, nomaden, mellem hans kone, som ikke forstår et ord af, hvad han skriver, hans dreng Giorgio og hans pige Lucia på vej mod galskaben. Her har De ham, åndsalfonsen der får sine bøger betalt af forstyrrede velgørerinder. Her har De Joyce, fordrukken i hvidvin, i færd med lidt efter lidt at tabe sit syn og alligevel klamrende sig til usandsynlige manuskripter, sande bibler som uophørligt renskrives (forlæggeren Garland har netop udgivet det New York, man bør se farverne på Ulysses-manuskriptet, den fine, utrættelige, flydende skrift). Her har De Joyce, hvis midlertidige sekretær er en ung mand ved navn Samuel Beckett, som vil omtale ham, engang. Her har De Joyce, den uforsonlige kunstner, dandy for evigheden, metafysisk anarkist, det bedste produkt af de jesuitter, hvis manglende interesse for litteratur til sidst frembragte den største moderne forfatter. Her har De James Joyce, hvor han har "erklæret det engelske sprog krig" og annonceret, at han "bliver ved til det sidste". Her har De Joyce, der aldrig tøver med at komme pa kant med hele Jorden, så snart det er hans værk, det drejer sig om Her har De ham, mens han forbløffes over Jungs, efter hans opfat- telse, uforskammmethed og undervejs gør opmærksom på, at for at finde grunden dertil rækker det at oversætte hans navn til tysk, Joyce $=$ Freud. Som havde man på fransk sagt Joyeux eller Joyaux ${ }^{3}$.

Alt i sproget! Alt for musikken! Her har De endelig Joyce, således som Mercantons vidunderlige bog, Les Heures de James Joyce 4 , viser ham for os: "Jeg vil arbejde til klokken fem om morgenen. Så går jeg til Saint-François-Xavier for at tage del i gudstjenesten. Hvis De vil ledsage mig, må De stå tidligt op." Og i august 1939: "Kan De da ikke lade Polen i fred og i stedet bekymre Dem om Finnegans Wake!" Ved hans begravelse i Zürich synger tenoren Max Meili Addio terra, addio cielo af Monteverdi. Stemmen, evigt og altid.

Kære franskmand, De holder ikke for meget af denne Joyce, De er underkastet ham mod Deres vilje. Ubehag og næsten censur ved N. R. F., Labaud undtaget. "Falsk mesterværk" knurrer Gide om Ulysses. Fjendtlighed hos Breton og surrealisterne på trods af Soupault (hver gang finder Joyce altså en oversættende hengivenhed). Retssag i London; forbud i New York. Fordømmelse ved Radek i Moskva. Den enes såvel som som den andens uvidenhed. Hvilken tænker, hvilken filosof var virkelig klar over, at på den side af diktionen og sangen stod alt og skælvede natten før det tredje tusindårsrige? At man nu endelig forlod det af Proust så beundringsværdigt afrundede 19. århundrede? Forsøger Lacan at hænge på? Hvorfor ikke? Skam og ulykke, undseelighed og bagtalelse, just dér finder De vor vokaleventyrers eksistens. Den eneste avis, som hilste udgivelsen a Finnegans Wake velkommen var il "Osservatore Romano". "En gammel kardinal", siger Joyce, "der ville drive gæk med mig."

"Talens magt", skriver Poe. "Epifani", svarer Joyce (epifani af græsk épiphaneia: tilsynekomst). Det forekommer mig meget signifikant, at tre indspilninger af forfatterstemmer råder i den første halvdel af det 20. århundredes benhus. Den af Joyce læste recitativ af Finnegans Wake som en nøgle til den fremtidige verden. "For at gøre en ende på Guds dom" af Antoin Artaud. Pladen, hvor Céline endelig syntes at improvisere over sin romankunst (den berømte affære om de "tre punktummer", igen et spørgsmål om interpunktion, altså om øre). Joyce, Artaud, Céline. Luk Dem inde et par måneder med det, og De vender ikke hel tilbage fra Deres værelse. De bliver talt til fra en anden verden i en anden rytme, de bliver ført prestissimo mod en anden afgrund. Anden rædsel. Andet modangreb. Anden latter.

Det er ærgeligt, at Joyce ikke blev bedt om at indspille Mollys monolog, som hele verden tror at kende. Man ville have set det, man ville have set, i særdeleshed at en mand, der i den grad er i stand ti at skrive en kvinde indefra, vender op og ned på psykologiens an- 
naler. Men Joyce lod en anden nøgle indspille. Det er foredraget om Ulysses, hvor det er Moses, det handler om. Agypterne forsøger at overtale profeten til at lade sig rive med af strømmen fra tidens store civilisation. Israel er svagt, uden ressourcer, hvorfor være stædig, hvorfor ikke bare prise Isis og Osiris, Horus, Amon-Re? Svaret, som her gives, er svaret fra enhver forfatter, der har haft sin åbenbaring, det er svaret fra den udfordring, som endnu skal komme, det er Joyces eget. "Mine damer og herrer, havde den unge Moses imidlertid givet efter for og accepteret denne måde at anskue tingene på; havde han bøjet hovedet og underkastet sin vilje og selve sin sjæl denne uanstændige formaning, da havde han aldrig befriet det udvalgte folk fra dets trældoms hus, ejheller fulgt skystøtten ved dagslys. Han ville aldrig havde talt med Evigheden blandt lynglimtene på Sinais tinde og ville aldrig have vendt tilbage med ansigtet oplys af inspirationens bål og med Lovtavlerne i sine arme, prægede i de lovløses sprog". Dér igen er det nødvendigt at høre humoren, gløden og glæden i Joyces stemme. Han ved, at han skal vinde. Det er fatalt.

Noter

1. Indspilningen foretaget i London august 1929 til C. K. Ogden. 2. Gallimard 1962

3. Joyeux, adj.: glad, munter; Joyaux, n., pl. af joyau: smykke, juvel. O.a

4. L'Age d'homme, 1967.

\section{Oversat af Peer F. Bundgaard}

Teksten er fra: "La voix de Joyce", oprindeligt trykt i Théorie des Excep tions, Gallimard 1986, Paris.

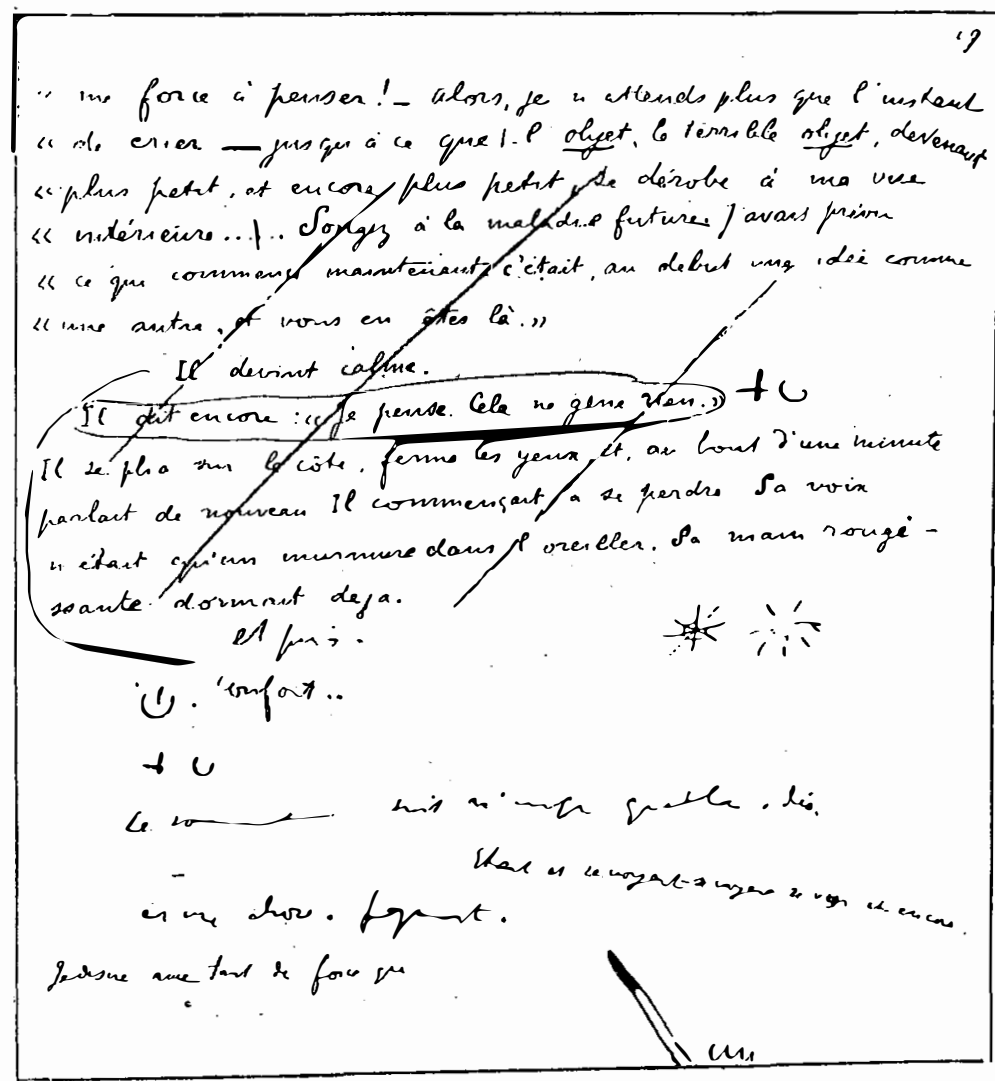

Paul Valéry. Fra manuskriptet til Soirée avec Monsieur Teste. 